\title{
18 Years of Decentralization Experiment in Indonesia: Institutional and Democratic Evaluation
}

\author{
Rudy $^{1}$, Yusnani Hasyimzum ${ }^{1}$, Heryandi ${ }^{1} \&$ Siti Khoiriah $^{1}$ \\ ${ }^{1}$ Faculty of Law, University of Lampung, Lampung, Indonesia \\ Correspondence: Rudy, Faculty of Law, University of Lampung, Lampung, 35145, Indonesia. Tel: \\ 62-811-7232-814. E-mail: rudy.1981@fh.unila.ac.id
}

Received: August 23, 2017

Accepted: September 20, 2017 Online Published: November 29, 2017

doi:10.5539/jpl.v10n5p132

URL: https://doi.org/10.5539/jpl.v10n5p132

\begin{abstract}
Big Bang decentralization in Indonesia had been begun since 1999 as the appeasement of many problems facing Indonesia after the fall of authoritarian rezim in 1998. This path had been suggested as all solution on local development by international donors such as World Bank and supported by many experts. Within the context, this paper evaluates the experiment of decentralization in Indonesia within the perspective of good governance and democracy. Using institutional design analysis coupled with empirical observation, this paper examines the problem within the legal institutional instrument and democratization in the local level.
\end{abstract}

Keywords: decentralization, democracy, institutional design, evaluation

\section{Introduction}

Decentralization has been very popular in the world at the beginning of millenium (Dillinger, 1994). This movement is very massive especially for developing countries. Most of developing countris around the world are now implementing decentralization, including Indonesia since 1999. Most of those countries has been suggested to believe that this path is able to stimulate economic development or ending the poverty in developing countries. Several others took this path to share the burden of central government on public service delivery. In many ways, this policy was taken by most of developing countries to solve their complicated problems.

For Indonesia, decentralization policy in the form of local authonomy is recognized by the Article 18 of 1945 Constitution, guaranteeing regions rights of autonomy and their legal origins. The constitution recognition, however, it is not implemented substantively since Independence Day. New Order government (1966-1998) took centralization stance covered by the framework of Unitary state. As result, multi level structure of local government were built under the law on government in the regions No. 5 year 1974. By this system, centralization has grown powerfully in all regions across Indonesia. New Order fall in 1998, gave some hope for the fulfillment of decentralization rights guaranteed by the constitution.

The falling out of new order goverment has opened the door for many agenda reforms, such as democracy, constitutionalism, and decentralization. Specifically, decentralization force had been evident as the growing concern of national unity. Thus, Big bang decentralization had been decided and started in 1999, with the enactment of decentralization law. The first Law was enacted in 1999 and it was effective in 2001. It underwent the next revision three years later, in 2004. Ten years later, in 2014, it was revised again through the enactment of Law No. 23/2014 on Local Government. The revisions brought changes in the distribution of governmental functions among the central and the provincial or district/municipal governments.

The shifting from centralization onto decentralization theoretically may enhance the ability and accountability in building the good governance and democracy in the regions. By this shifting, local government will have more power to empower their comparative advantage. This big change will have implication on the problem of adjustment of local government and central government power. This will also create implications in terms of adjustment or addition to provincial policies and organizational structures.

This year marks the 15 years of Indonesia experiment on decentralization. After many years of implementation, the academic review of its implementation is urgently needed, especially because Indonesia has been bringing many changes as the result of decentralization path. It raises a simple research question of the examination of decentralization model implemented in Indonesia. 


\section{Review of Preceeding Research}

Decentralization is often considered as a shift of authority towards local governments and away from central governments. Academic efforts to describe and determine decentralization has focused mainly on political, economic, and administrative aspect of decentralization.

Stephens (1974) argue that country with decentralization policy will have strong local government that has more power on managing the public policies in the regions, including the public need distribution, encompassing the goods and services. Manor (1999) argue that decentralization policy will bring more democracy and independency to the local government. Moreover, the participatory local government is also the benefit of decentralization policy (Smoke, Gomez, and Peterson, 2006). Conyers (1986) is in the same wave of many other experts to see the decentralization as the source of democrative local government and local community. Gomez (2006) illustrate that institutional design and participatory governance has been worked by new democracies over past two decades.

For many scholars, especially Manor (1999), the political range of decentralization is hugely important to achieve the goal of decentralization. Along with this, Smith (1985) also mentions that politically, decentralization could benefit the nation state building since this policy is bringing more political stability by giving the local people what they need. Moreover, it provides training ground for citizen involvement and political leadership, both local and national. In brief, scholars such as Jones (1985), Cheema and Rondinelli (1983) and Crook and Manor (1998) argue that decentralization and the creation of local governments reflect a commitment to pluralism, as well as promoting democracy.

Furthermore, the economic range of decentralization involves the financial transfer to regions and the improvement of local economy. Smith (1985) mentions that economically, decentralization could improve the efficiency of public services, as well as reduce the cost, improve outputs and more effectively utilize human resources.

The administrative range of decentralization is involving the formulation of administrative stucture and power between local and central government. Jun and Wright (1996) suggested that the administrative features is involving the transfer of power from central government to local government with the formulation of relationship between the central and local government.

Many studies in decentralization take these purposes as granted, and conclude that the failure of decentralization is seen as the failure of some part of implementation and not because of the model itself. Several expert is suggesting that uncomplete decentralization will have impact on the success of decentralization (Dillinger 1995; Seabright 1996; Agrawal and Ribot, 1999). It tells about another sub-hypothesis that the model of decentralization itself might be the core problem of why the decentralization purposes are not achieved.

Thus, the challenge for most developing countries governments is to get the suitable balance on decentralized systems and find the most proper model that serves the best of each country characteristic. The optimal mix is not easily decided. It shifts as social, economic and political conditions change (Rondinelli, 1983).

Smoke (2005) stressed that the result of decentralization variously affected by many dimensions and aspect. In the other hand, the vast body of literature on decentralization gives us many dimensions of the studies of decentralization.

Impartially crucial is that many research conducted by many expert is not giving stresses on processes that influence the design of decentralization and its dynamic between local government and central government (Smoke, Gomez, and Peterson, 2006). Only a few recent publications consider the role of history in decentralization, including Eaton (2004) and Falletti (2005).

\section{Method}

Within the context of legislation development aspect of decentralization, this paper will evaluate the implementation of decentralization in the forma of local autonomy. In this case, historical legal approach can tell a lot of law and policies phenomena of different decentralization law models that were chosen in different period during the process; The development of laws and policies, how has the law and its institutions acted as historical forces? How has history wielded its influence upon law and policies? Historical legal approach can look at the way in which law is shaped by dynamic relationship between law and social political forces throughout Indonesian history. Laws and policies changes by this approach can be traced through the interpretations and development of law model during each period and thus contribute to an analysis of the shaping of legal institutions from the good governance and democracy point of view. 


\section{Discussion}

\subsection{Institutional Development: Proper Balance is needed}

Post independence Indonesia has been marked by the law changes continuously up to 1974 (Law No. 1 Year 1945; Law No. 22 Year 1948; Law No. 1 Year 1957; Law No. 18 Year 1965). Decentralization framework had been put in each levels of local governments consist of province, municipality/regency, and village. During this period, these levels of local government especially province has the authority in regions as the central government had been busy with the national level institutional setting. Under Law No. 5 Year 1974, New Order Administration maintained strong fiscal and political control over provinces and municipalities/regencies through central field agencies in the regions by the principle of deconcentration.

By the law, New Order Government was determined to control all the policy of local government in the regions. This determination is also motivated by the threat of local separatism threats and extreme political movements from the left community or right community. The thingking of that stability runs well based on planning that is able to handle the separatism groups but the way that is chosen also gives bad impact for the local government because concept of decentralization is very closed by central government so local government runs only based what is determined by it.

Therefore, implementation of local autonomy in the new order brought unsatisfied result because local government became only representative of central government and very centralistic. It can be seen from strong supervision of central government. It certainly eliminates local wisdoms and only uniforms based on authority of central government.

Into the decade 1990's, New order government began for showing its weaknesses that got great criticism, because it was too centralistic and it also brought up corruption, collusion, and nepotism significantly. In 1997 there was monetary crisis and the bad situation that was not controlled. It developed being multidimensional crisis in long term. Along that turmoil, globalization dan world people development that was very transparent and full of information, encouraged the existence of great changing in the world. Indonesian citizen responded by demanding freedom, transparation, justice, democracy were based on value of human rights, responsibilty, people savety as soon as possible.

The fall of New Order Government marked the demand on the new formulation on the relationship between central government and local government. This demand has been escalating as the result of the dissappointment of central-local arrangement involving economic sharing and political participatory. (Malley, 1999). The result of this historic event was the passing of Law No. 22 year 1999 about local government with the intention of giving local rights in regulating and managing its own government household and welfare and national development.

Indonesia, compared to many others developing countries, took the big bang decentralization approach in the form of local autonomy law. With some limitations, local autonomy law made all de-concentrated central government ministries in the provinces and municipalities/regencies responsible for their respective local governments. The exceptions were for the autority which is naturally belong to central government such as foreign affairs and judiciary among others.

The introduction of Law No. 22 Year 1999 change the shape of intergovernmental relationship and local management in many ways. Under Law 22 Year 1999, which provided the scheme for political and financial devolution, the regencies and municipalities assumed new responsibilities that were previously undertaken by the national government, as well as managing new financial resources that had been transmitted from the central government or raised within their own localities.

The municipalities/regencies became fully independent. By this system, heads of municipalities/regencies have no hierachical relation with the governor, thus, they have no obligation to responsible to the Governor. Instead, heads of local governments had to responisble to the local assembly. In contrast, provinces retained a hierarchical relationship with central government. The independence of the region was described more in Article 1 number 1 of local autonomy law 1999 stating that Autonomous Region is the legal unity of the society that owns a certain restricted territory, has the power to regulate and manage the interests of the local society based on their own initiative according to the aspirations of the people.

Consequently, the regencies also municipalities were regarding themselves as the local government that responsible directly to central government, rather than the province. Some representatives of regencies and municipalities elected representative assemblies (DPRD) even doubted the authority of the provincial assembly in their region. Regents also mayors had ignored the governor in many occasions. Instead of coming by them to coordination meeting, regents and mayors tend to send their deputy secretary to the meeting. This condition 
obviously made the coordination function of provincial local governments was not achieved.

The local executive-legislative relationship becomes one of dynamic decentralization process during this period. The law 22 Year 1999 put the local assembly as the institution that have power to elect the head of local government. Based on Law No. 22 Year 1999, the local assembly has the authority to elect governors, regents and mayors. The President must confirm these elections, but unlike Law No. 5 Year 1974 framework, the President cannot refuse the outcome.

Regardless of its deficiencies, it is normally received by many pundits that the passage of local autonomy law has changed the face of central local relation in Indonesia.

Five years implementing decentralization after reformation already ran well based on law that regulated it. But that decentralization period still got critics from various parties, with the intention of society welfare. Therefore, in 2004, that law was changed for several purpose.

Another reason of amendment of Law no. 22 year 1999 to Law No. 32 year 2004 is paying attention to the relationship between Province and regency/municipalities that was totally separated. Megawati as president at that time also argued that local autonomy already worked too far, also it was impressed like overflow and threated national integration.

Author argue that basic essence of amandment of local government law is because there is the amendment of 1945 constitution of Indonesian republic so automatically regulation of local government is necessary to be changed based on the applicable constitution. In addition, there is unclear relationship and interpendency between levels and arrangement of government especially between local and central government also provincial government with regencies/municipalities.

In line with Law 22 Year 1999, Law 32 Year 2004 gives the central government absolute authority in several affairs which is belong to central government such as foreign affairs, finance, judiciary, defense, and religious matters. Then, all other government affairs have been divided proportionally among central government, provinces, and municipalities/regencies based on three criteria: externality, accountability, and efficiency.

However, Law 32 Year 2004 dismissed the residual system of government affairs which is belong to local governement according to previous law. Law 32 Year 2004 instead gives list of local government affairs in the form of obligatory functions and discretionary functions. The running of mandatory government affairs are based on the minimum standard of service is administered in stages and stipulated by the Government (Article 11 (3), (4) Law No. 32 Year 2004). Selected government affairs that factually and potentially improve public welfare in corresponding to the condition, uniqueness and superiority potential of the regions concerned (Article 13 (2) and Article 14 (2) Law No. 32 Year 2004)

After 12 years of decentralization policy, Law No 23 Year 2014 has been signed to put the greater balance on the decentralization policy. Generally, the authority of local government is not so different with the previous law. This law in several field has taken the authority from municipalities to province such as authority on the coastal management, mining, and senior high school education. The important changes of the law is the formulation of village authority which is then strengthened in the specific law No 6 Year 2014.

The reason of that Law replacement is for improving law of local government that gives decentralization to local area based on characteristics of local society. Law No. 32 year 2004 is regarded successfully but in its implementation still arises new problem that is necessary to get attention from central government. The different interpretation on the law from various interest groups becomes one of conflict source from various governments and its apparatus. In addition, the obligatory and discretionary affairs that is abundant in several case had made the burden of local government. Generally, the new law tried to find out clear point as an improvement attempt of local goverment service for accelerating development and prosperity of society.

In line with law above, governors nowadays have the authority to watch over the municipalities/regencies. This condition is double-edged coin for the future of Indonesian decentralization. The outcome will not be fruitful if the governors make the power for justification to constrain the municipalities/regencies in implementing the local autonomy. In the other side, this new framework can bring the better outcomes for decentralization in Indonesia if the governor and regents/mayors makes it as the check and balances mechanism in the regions so that the mutual benefit can be achieved.

\subsection{Development of Local Regulation}

Decentralization policy gave more room for local government to have creativity over the policy in the region. In this period of local autonomy, best practices and innovations usually came from the dominant control of 
executive-led local government. It is not balanced by the initiative of local assembly on the local development. Therefore, the limit the local initiative and best practice in the regions may be halted by the limit of local government head period. (World Bank, 2006). As the World Bank (2006) pointed that the local development had been characterised by local government head led development and did not supported by the strong local regulation. Instead the local government was using the administrative instrument rather than local regulation.

In the same time, local regulation has been fluorising in the beginning of the decentralization policy in Indonesia. there are still local governments ignore the importance of sound investment law and policies in the framework of governance. For example, each local assembly has enacted an average of more than 30 local regulations per year (Matsui, 2005). Most of those regulation are not designed for the local development but only chasing the local income in the form of tax and levies.

Large body of studies has described the negative impact of decentralization on investment since 2001 in Indonesia. Low level of public services and proliferation of nuisance local regulation picture the condition of local development in Indonesia. Abundant requirements makes the license approval seems so difficult to obtain by local community and business circle. Spirit and culture to control inherited from centralized system in fact still strong in local government bureaucracies in Indonesia. In 2008, the Law No. 28 Year 2009 on Local Tax and Levies had been enacted by Central Government to reduce and to limit the negative impact of nuisance of local regulation. This Law has been evident very successful on pushing local government to meet up the standard of tax and levies in regions.

In addition, the development of law in the region may be characterised as copy-paste from the central government. Our research on the legislation development show that local regulation mainly focuses on the institutional building, local tax and levies, and regulation that is made as the instruction from the central government. These are still the problem facing Indonesia Decentralization and become barriers for creating and innovate sound policies and good regulation. The region in the future shall make the local regulation as the tool for local development.

Authors argue that local regulation is the important element for local development, if planned and formulated based on the need of local development. The local regulation shall have supported the local development planning and become the backbone of local development. In the future, the quality of the local regulation shall be improved in supporting local development.

\subsection{Local Direct Election}

The decentralization policy shall be supported by the democratic consolidation. This thinking was accomodated in the system of direct election under the framework of Law No. 32/2004 and Law No. 23/2014. Direct election system is the system which is local people can elect their local leader directly. This system is not regulated in the previous law No. 22/1999 on Local Government. Law No. 22/1999 gave the authority to elect the local government head in the hand of local assembly member. The election by local assembely member had been colored by many gratification and bribery, thus giving bad name to the local democracy.

The existence of this law has encouraged the rise of figures Local to perform a regional leader. Changes in legislation rolling by introducing Law No. 32 of 2004, which further strengthen the democratic process at the local level directly. Implementation of the Law for the first time held successfully in June 2005 in 191 districts. In the second election of 2010 there are 244 provinces/districts/cities that generate the configuration of new actors who come from diverse origins and the local community itself.

Direct elections since 2005 have been regarded as success story of local democracy in Indonesia. This election, although expensive, has been successfully avoiding political violence, riots, and social conflicts that are often feared by many pundits. In perspective Schumpeter, of procedural democracy, Indonesia has reached the point of encouraging success.

These success stories leave some evaluation of local elite rise and the problem of corruption in the local level. Similarly, the phenomenon of corruption in a brightly-lit present in public not only at national level but also spread to various regions during the years 2005-2012. Data shows the results of the direct election of regional heads that caught the problem of corruption in the regions. The corruption has been linked to the political dynasty in some regions in Indonesia. In the end, the accountability required by the successfull decentralization policy has not been achieved in many regions.

\subsection{Village Empowerment}

In early 2014 a new policy emerged specifically governing villages, namely Law No. 6 of 2014 on the village. Villages Act was passed on December 18, 2013 and entered in gazette No. 6 of 2014 on January 15, 2014 Law 
on the Village became a turning point in Indonesian village setting. Villages Act puts the village in accordance with the constitutional mandate to refer paragraph 2 of Article 18B and Article 18, paragraph 7.

Village Law is prepared by the spirit of the implementation of the constitutional mandate, the setting up of indigenous peoples in accordance with the provisions of Article 18B paragraph (2) and Article 18 paragraph (7) Constitution NRI 1945, by constructing and combining the functions of a self-governing community and local self goverrnment (Explanation of Law No. 6 About the Village), Therefore the constitutional basis for this will be a valid foundation for the future of the village in Indonesia. Efforts to optimize the village kept organized government for the welfare of Indonesian society.

Village authority includes the authority in the field of rural governance, the implementation of rural development, rural community development based on community initiatives, rights origin, and customs of the village. The authority of the village, namely:

a. Power based on the right origin;

b. Village-scale local power;

c. The authority commissioned by the Government, the Government of the Province of, or the Government of the District / City; and

d. Other authorities assigned by the Government, Provincial Government, or the Government District / City in accordance with the provisions of the legislation.

Village Act No. 6 of 2014 form the fabric of the village as a self-governing community and local administration. The order is expected to accommodate the unity of indigenous peoples who became the foundation of the Homeland diversity. From the perspective of the village itself is obviously necessary preparations so that the implementation of a comprehensive Village Act No. 6 of 2014 really can be optimized and well-being no longer just a dream of the villagers. The institutional design has been supported by the Government Regulation No. 43 Year 2014 which became the basis of the implementation of the Law on the Village. Village management includes aspects contained in the principles of good and clean governance. This village governance should include three main aspects, namely checks and balances between the head of the village with the village Consultative Board, the application of representative and deliberative democracy, participatory democratic process in the village meeting.

Explicitly stated that executive power holder must be supported by a system for implementing rural development. The government explained that the Village will be comprised of a village chief who led the village. Then, communities can choose the village chief that is competent and able to carry out rural development programs and structuring. The terms of the prospective chief of the village is contained in article 33 and the general election is set at the Village Chief Electoral Process of Article 34.

Regulation of the village is the juridical basis of each policy Village administration in the application of development programs and development. The village regulations made jointly by the Village Consultative Board with the approval of the chief. Rural communities through interest groups and village social institutions are also eligible to provide feedback to the Government aspiration or village.

Village communities should be involved in every process of rural development from planning, implementation, monitoring and supervision of rural development. In the rural community planning process that is already well represented by the Village Consultative Body or as individuals representing the interests and needs of specific communities involved in village meeting organized by the Village Head and Village. In the implementation phase, the villagers directly participate to the process of rural development in the spirit of mutual cooperation and utilize local knowledge and natural resources of the village. Forms of community participation in the monitoring and supervision of the village are an obligation for the technical implementation and development of the Village Chief to make accountability reports rural development projects in the village meeting at least once a year and in the rural communities of the forum have the right to respond to the report.

Related to development of local independent, central government is getting attention and emphasize the development of rural communities through the village administrative autonomy. Governance and with establishment of the village should be able to accustom the involvements of the people, realizing the active role of the community to participate and be responsible for the development of life together as fellow villagers

\section{Conclusion}

Indonesia has been implementing the policy of decentralization for more than eighteen years. There are many fundamental changes occurring during the implementation. Some conclusion unfolded, such as the need of 
proper balance of intergovernmental relations. More importantly, local initiatives regarding law institutions and the best policies are created to serve local development. However, direct election has double edged for Indonesia future since the aspect of accountability is not complete in some regions, instead creating the small king who does not respond to the local people. The future of decentralization policy is still rolling in Indonesia as the empowerment of village has been strengthened after more than 30 years of centralization and homogenization.

\section{References}

Agrawal, A., \& Ribot, J. (1999). Making Decentralization Accountable: A Framework for Analysis and Empirical Studies from South Asia and West Africa. Submitted to Comparative Politics.

Cheema, G. S., \& Rondinelli, D. A. (1983). Decentralization and Development: Policy Implementation in Developing Countries. Beverly Hills, CA: SAGE Publication.

Conyers, D. (1986). Future Directions in Development Studies: The Case of Decentralization. World Development, 14(5), 593-603. https://doi.org/10.1016/0305-750X(86)90126-9

Crook, R. C., \& Manor, J. (1998). Democracy and Decentralization in South Asia and West Africa: Participation, Accountability, and Performance. Cambridge: University Press.

Dillinger, W. (1994). Decentralization and its Implication for Urban Service Delivery. Urban Management Program Discussion Paper 16. Washington DC: World Bank. https://doi.org/10.1596/0-8213-2792-5

. (1995). Decentralization, Politics and Public Sector. In A. Estache ed., Decentralizing Infrastructure: Advantages and Limitations. Washington DC: World Bank Discussion Papers 290.

Eaton, K. (2004). Politics Beyond the Capital: The Design of Sub national Institutions in South America. Stanford, CA: Stanford University Press.

Falleti, T. (2005). A Sequential Theory of Decentralization: Latin America Cases in Comparative Perspective. American Political Science Review, 9(3), 327-346. https://doi.org/10.1017/S0003055405051695

Gomez, E. J. (2006). Decentralization's Horizontal, Vertical, and Policy-Fluctuation Mechanism: Method for Cross Regional Analysis. In Paul Smoke, Eduardo J Gomez, and George E. Peterson eds. Decentralization in Asia and Latin America: Toward Comparative Interdisciplinary Perspective. UK:Edward Elgar Publishing.

Indonesia. Undang Undang Republik Indonesia Nomor 1 Tahun 1945 tentang Pemerintahan Daerah. [Republic of Indonesia Law Number 1 Year 1945 regarding Local Government].

. Undang Undang Republik Indonesia Nomor 22 Tahun 1948 tentang Pemerintahan Daerah. [Republic of Indonesia Law Number 22 Year 1948 regarding Local Government].

. Undang Undang Republik Indonesia Nomor 1 Tahun 1957 tentang Pemerintahan Daerah. [Republic of Indonesia Law Number 1 Year 1957 regarding Local Government].

. Undang Undang Republik Indonesia Nomor 18 Tahun 1965 tentang "Pemerintahan Daerah." [Republic of Indonesia Law Number 18 Year 1965 regarding Local Government].

. Undang Undang Republik Indonesia Nomor 5 Tahun 1974 tentang “Pemerintahan Daerah.” [Republic of Indonesia Law Number 5 Year 1974 regarding Local Government].

Undang Undang Republik Indonesia Nomor 22 Tahun 1999 tentang "Pemerintahan Daerah." [Republic of Indonesia Law Number 22, 1999 regarding Local Government].

. Undang Undang Republik Indonesia Nomor 32 Tahun 2004 tentang "Pemerintahan Daerah." [Republic of Indonesia Law Number 32 Year 2004 regarding Local Government].

Undang Undang Republik Indonesia Nomor 28 Tahun 2009 tentang "Pajak dan Retribusi Daerah." [Republic of Indonesia Law Number 28 Year 2009 regarding Local Tax and Levies].

. Undang Undang Republik Indonesia Nomor 6 Tahun 2014 tentang "Desa." [Republic of Indonesia Law Number 1 Year 1957 regarding Village].

Undang Undang Republik Indonesia Nomor 23 Tahun 2014 tentang "Pemerintahan Daerah.” [Republic of Indonesia Law Number 23 Year 2014 regarding Local Government].

Jones, G. (1985). Conclusion: Implication for Policy and Institutions. In S. Ranson. G. Jones, \& K. Walsh (Eds.), Between Centre and Locality: The Politics of Public Policy. London: George Allen \& Unwin.

Jun, J. S., \& Wright, D. S. (1996). Globalization and Decentralization: An Overview. In Jun, Jong S., \& Wright, 
Deil S. (Eds.), Globalization and Decentralization: Institutional Context, Policy Issues, and Intergovernmental Relations in Japan and the Unites States. Washington, D.C: Georgetown University Press.

Malley, M. (1999). Regions: Centralization and Resistance. In D. Emmerson (Ed.), Indonesia Beyond Suharto: Polity, Economy, Society, and Transition. New York: ME Sharpe.

Manor, J. (1999). The Political Economy of Democratic Decentralization. Washington, DC: World Bank. https://doi.org/10.1596/0-8213-4470-6

Matsui, K. (2005). Post-Decentralization Regional Economies And Actors: Putting The Capacity Of Local Governments To The Test. The Developing Economies, XLIII-1: 171-89. https://doi.org/10.1111/j.1746-1049.2005.tb00257.x

Rondinelli, D. A. (1983). Implementing Decentralization Programs in Asia: A Comparative Analysis. Public Administration and Development, 3, 181-207. https://doi.org/10.1002/pad.4230030302

Seabright, P. (1996). Accountability and Decentralization in Government: An Incomplete Contracts Model. European Economic Review, 40. https://doi.org/10.1016/0014-2921(95)00055-0

Smith, B. C. (1985). Decentralization: The Territorial dimension of The State. London: George Allen and Unwin.

Smoke, P. (2005). The Rules Of The Intergovernmental Game In East Asia: Decentralization Frameworks And Processes in East Asia Decentralized. Washington. DC: The World Bank.

Smoke, P., Gomez, E. J., \& Peterson, G. E. (2006). Understanding Decentralization: The Need for a Broader Approach. In P. Smoke, E. J. Gomez, \& G. E. Peterson (Eds.), Decentralization in Asia and Latin America: Toward Comparative Interdisciplinary Perspective. UK: Edward Elgar Publishing.

Stephens, R. G. (1974). State Centralization and the Erosion of Local Autonomy. Journal of Politics, 36(1), 44-76. https://doi.org/10.2307/2129110

World Bank. (2006). Making Services Work for the Poor: A Synthesis of Nine Case Studies from Indonesia. Prepared by Susannah Hopkins Leisher and Stefan Nachuk.

\section{Copyrights}

Copyright for this article is retained by the author(s), with first publication rights granted to the journal.

This is an open-access article distributed under the terms and conditions of the Creative Commons Attribution license (http://creativecommons.org/licenses/by/4.0/). 